\title{
Kemampuan Manajerial Pendidikan Islam dan Penerapan Manajemen Waktu oleh Ketua Prodi PTKIS dalam Menghasilkan Lulusan Tepat Waktu di Kota Batam.
}

Tabri Waluyo,

UIN Sultan syarif Kasim Riau,

Email : tabriwaluyo@gmail.com,

\section{Hairul Huda}

Universitas Muhammadiyah Jember

Email : hairulhuda@unmuhjember.ac.id

Submission
Track:
Received:
2 Februari 2020
Final Revision:
1 Maret 2020
Available online:
25 Maret 2020
Corresponding
Author:
Name \& E-mail Address
Tabri Waluyo,
tabriwaluyo@gmail.com,
Hairul Huda
hairulhuda@unmuhjember.ac.id

\begin{abstract}
Abstrak
Kompetensi berupa kemampuan menejerial yang dimiliki pemimpin digunakan sebagai alat dan potensi sumber daya untuk menuju efisien dan efektif dalam penerapan manajemen waktu, maka kemampuan tersebut diharapkan dapat menghasilkan lulusan tepat waktu pada mahasiswa PTKIS Kota Batam. Tujuan dari penelitian ini (1) untuk mengetahui kemampuan Manajerial Pendidikan Islam ketua prodi (2) Untuk mengetahui penerapan manajemen waktu oleh ketua prodi (3) Untuk mengetahui perkembangan mahasiswa lulusan tepat waktu (4) Untuk mengetahui pengaruh kemampuan Manajerial Pendidikan Islam ketua prodi terhadap lulusan tepat waktu di PTKIS Kota Batam (5) Untuk mengetahui pengaruh manajemen waktu terhadap lulusan tepat waktu (6) Untuk mengetahui pengaruh kemampuan Manajerial Pendidikan Islam dan manajemen waktu secara bersamasama terhadap lulusan tepat waktu. Hasil penelitian ini menunjukkan bahwa: (1) kemampuan Manajerial Pendidikan Islam ketua prodi tergolong tinggi dengan memperoleh score angket $81.1 \%$ (2)Penerapanmanajemen waktu oleh ketua prodi dikategorikan tinggi karena presentasi tersebut mencapai 83\% (3) Perkembangan mahasiswa lulusan tepat waktu di PTKISKota Batam adalahmencapai $81 \%$ dari hasil data ideal(4) kemampuan Manajerial Pendidikan Islam berpengaruh secara parsial terhadap lulusan tepat waktu, hal ini ditunjukkan oleh nilai $T^{\text {hitung }} 4.963>T^{\text {tabel }} 3.182$. (5) Manajemen waktu tidak berpengaruh secara parsial kepada lulusan tepat waktu, hal ini ditunjukkan oleh nilai Thitungadalah $2.654<$ dari $\mathrm{T}^{\text {tabel }} 3,812$ (6) secara bersama-sama kemampuan Manajerial Pendidikan Islam dan manajemen waktu berpengaruh terhadap lulusan tepat waktu, hal ini ditunjukkan oleh probability value uji F sebesar 0,001<0,05. dan Fhitung148.643 > Ftabel 6,94.
\end{abstract}

Kata Kunci : 'Kemampuan Manajerial Pendidikan Islam, Manajemen waktu,lulusan tepat waktu.

\section{PENDAHULUAN}

Lulus tepat waktu adalah tanggung jawab moral seorang mahasiswa. Tetapi, itu saja tidak cukup. selain bisa menyelesaikan studi sesuai target waktu, mahasiswa juga harus betul-betul menguasai bidangnya setelah berpredikat lulus menyandang sebuah gelar.lulus tepat waktu itu menguntungkan karena dapat menghemat biaya, umur, waktu, serta tenaga. Hal ini sesuai dengan undang undang no 12 tahun 2012 bab I pasal 5b tentang pendidikan tinggi yang berbunyi : " dihasilkannya lulusan yang menguasai cabang IlmuPengetahuan dan/atau
Teknologi untuk memenuhikepentingan nasional dan peningkatan daya saing bangsa ".

Banyak faktor yang diduga menjadi penyebab bagi mahasiswa dapat menyelesaikan studinya di kampus-kampus PTAIS Kota Batam diantaranya adalah motivasi belajar, manajemen waktu, lingkungan, dan iklim belajar kampus serta kemampuan Manajerial Pendidikan Islam Ketua Prodi dalam memimpin program studinya. Sebagaimana yang diamanahkan undang undang no 12 tahun 2012 pasal 33 ayat 2, yang berbunyi : "Program Studi memiliki kurikulum dan 
metodepembelajaran sesuai dengan program

Pendidikan".

Mendukung mahasiswa agar dapat menyelesaikan studinya tepat waktu ada banyak cara, diantaranya adalah kemampuan Manajerial Pendidikan Islam dari Ketua Prodi, manajemen waktu yang bagus, dan lain-lain. Aspek tersebut apabila diterapkan dengan benar dan saling mendukung maka akan tercipta singkronisasi dalam dunia perkuliahan sehingga mahasiswa yang sambil bekerja akan dapat menyelesaikan kuliahnya tepat waktu. Kebijaksanaan ketua prodi dalam menetapkan kalender perkuliahan yang mengikuti jam kerja namun tetap dapat melaksanakan agenda perkuliahan dengan baik. Sehingga mahasiswa dapat menyelesaikan masa perkuliahan tepat waktu sebagaimana yang diamanatkan undang undang no 12 tahun 2012 bab II pasal 13 b yang berbunyi: "Mahasiswa dapat menyelesaikan program Pendidikansesuai dengan kecepatan belajar masingmasing dantidak melebihi ketentuan batas waktu yang ditetapkan oleh Perguruan Tinggi “.

Ada banyak hal yang bisa memicu seorang mahasiswa tidak lulus tepat pada waktunya, yaitu sulitnya skripsi, masalah ekonomi, atau bahkan dosen pembimbing yang tidak cocok. Namun, sebenarnya hal ini bisa menjadi proses pendewasaan. Nantinya akan lebih siap untuk menghadapi dunia kerja selepas kuliah. Menjalani kuliah di perguruan tinggi adalah sesuatu hal yang sulit dan penuh tantangan, dikarenakan karakter mahasiswa yang merupakan karyawan dan pekerja di berbagai perusahaan. Sehingga membatasi waktu untuk belajar dan mengharuskan mahasiswa untuk menyesuaikan waktu dengan jadwal kerja mahasiswa.

Besarnya jumlah angkatan kerja kaum muda dari berbagai daerah yang saat ini sedang bekerja di
Kota Batam khususnya, dimana mahasiswa belum sempat merasakan bangku kuliah, tentu ini adalah peluang dan tantangan tersendiri bagi perguruan tinggi di kota batam, bagaimana agar mahasiswa tetap dapat bekerja sekaligus kuliah dan selesai tepat waktu. Berdasarkan studi awal penelitian ke beberapa kampus di kota batam, melalui wawancara secara lisan dengan beberapa Ketua Prodi dan lima Mahasiswa yang saat ini sedang mengalami keterlambatan studi pada Hari Selasa, 30 Oktober 2018 didapatkan bahwa sebagian besar mahasiswa masih kesulitan mengikuti perkuliahan sambil tetap bekerja, sehingga sering datang terlambat, tidak menjalankan tugas, sering absen dan akhirnya kuliah menjadi terbengkalai tidak cepat selesai.

Berbagi waktu antara kerja dan kuliah menjadi tantangan tersendiri bagi kalangan mahasiswa kota batam, mulai dari sulitnya menyelesaikan tugas dosen, mengikuti kegiatan kampus maupun tingkat kehadiran yag rendah dan seringnya datang terlambat. berbagai kendala itu yang menjadi penghambat bagi mahasiswa untuk menyelesaikan kuliah tepat waktu di sebuah perguruan tinggi. Kuliah sambil bekerja, menjadi kendala mahasiswa dalam menyelesaikan masa studinya. (Tribunews, 2018).

Kenyataan diatas disebabkan oleh berbenturannya jadwal kuliah dengan waktu kerja yang menggunakan Rolling Shift sehingga tingkat ketidakhadiran menjadi tinggi, kemudian menurunkan semangat mahasiswa dalam menyelesaikan tugas-tugas kuliah karena rendahnya penyerapan materi dari mata kuliah dan kurangnya waktu untuk mengerjakan tugas, sehingga nantinya menjadikan mahasiswa untuk memilih berhenti/cuti. 


\section{METODE PENELITIAN}

Penelitian ini merupakan jenis penelitian kuantitatif dengan pendekatan yang bersifat korelatif, untuk mengetahui, untuk menemukan ada tidaknya hubungan / pengaruh. Apabila ada hubungan, seberapa erat hubungan dan berarti atau tidak hubungan itu, melalui perlakuan antara dua atau lebih variable yang diteliti. Peneliti akan meneliti tentang kemampuan Manajerial Pendidikan Islam ketua Prodi perguruan tinggi di lingkungan PTKIS Kota Batam dan penerapan manajemen waktu dalam kalender perkuliahan serta tingkat kelulusan mahasiswa di dalamnya, mulai bulan April - September 2019. Sedangkan penelitian ini akan bertempat di Perguruanperguruan tinggi agama islam di lingkungan PTKIS Kota Batam, yaitu: STAI Ibnu Sina Batam, STIDKI Al Aziz batam, STIQ Kepri dan STIE Ar-Rachman.

Jumlah populasi yang akan diteliti pada penelitian ini adalah enam responden ketua prodi yang berada di empat Perguruan Tinggi Keagamaan Islam /PTKIS Kota Batam yang telah menghasilkan lulusan mahasiswa sebagai hasil dari proses perkuliahan yang telah mahasiswa jalankan. Data yang dibutuhkan dalam penelitian ini sesuai dengan variabel $\mathrm{X}^{1}$, $\mathrm{X}^{2}$ dan $\mathrm{Y}$ adalah sebagai berikut:

1. Data yang dibutuhkan untuk variabel $\mathrm{X}^{1}$ Kemampuan Manajerial Pendidikan Islam adalah:

a. Perencanaan dari ketua prodi terhadap lembaga pendidikan yang dipimpinnya.

b. Pengorganisasian oleh ketua prodi terhadap perkuliahan pada prodinya

c. Pelaksanaan program yang telah dicanangkan oleh ketua prodi d. Evaluasi terhadap kinerja dan pencapaian dari program kerja

2. Data yang dibutuhkan untuk meneliti Variabel $\mathrm{X}^{2}$ Manajemen waktu dari ketua prodi

a. Penentuan skala prioritas pencapaian target dalam tujuan perkuliahan.

b. Penjadwalan yang rapi dan sistematis sesuai kalender akademik.

c. Mengorganisir waktu dengan efektif dan efisien dalam pelaksanaan perkuliahan.

d. Memiliki produktifitas dalam pengajaran dan prestasi.

3. Sedangkan data yang dibutuhkan dalam meniliti variabel Y lulusan tepat waktu adalah

a. Mahasiswa dapat menyelesaikan studi S1 kurang atau selama 4 tahun.

b. Mahasiswa mampu mengikuti perkuliahaan sesuai dengan kalender pendidikan yang telah ditetapkan.

Adapun keterkaitan dan hubungan dari kemampuan Manajerial Pendidikan Islam (X') dan manajemen waktu $\left(\mathrm{X}^{2}\right)$ terhadap variabel $\mathrm{Y}$ lulusan mahasiswa tepat waktu akan diteliti seberapa besar keterkaitan dan hubungannya dalam penelitian ini. Apakah masing-masing variabel $\mathrm{X}$ secara terpisah/parsial memiliki hubungan terhadap variabel $\mathrm{Y}$ atau secara berama-sama memiliki hubungan terhadap varibel Y. Sugoyono, (2019 : 74). Adapun ukuran data yang dibutuhkan dalam penelitian ini adalah menggunakan rating scale karena lebih fleksibel, tidak terbatas untuk pengukuran sikap saja tetapi untuk mengukur persepsi reponden terhadap fenomena lainnya, seperti skala untuk mengukur status sosial ekonomi, kelembagaan, pengetahuan, kemampuan, proses kegiatan dan 
lain lain. Menurut Hadi (1991), perbedaan Rating scale dengan skala likert adalah kalau skala likert menggunakan 5 skala penilaian, sedangkan rating scale hanya menggunakan 4 skala. Karena pada skala likert kategori undeciden mempunyai arti ganda, bisa diartikan belum dapat memutuskan atau memberi jawaban.

Penelitian ini menggunakan teknik pengumpulan data yang berupa angket, wawancara dan dokumentasi yang dilakukan langsung kepada ketua Prodi untuk mendapatkan data-data yang terkait agar dapat menganalisa kemampuan Manajerial Pendidikan Islam seorang ketua Prodi dan penerapan manajemen waktu pembelajaran pada lembaga yang dipimpinnya, serta perkembangan lulusan mahasiswa pada lembaga pendidikan yang dipimpinnya.

Instrumen peneltiian yang digunakan dalam kemampuan peneltiian ini berupa angket, pedoman wawancara dan dokumen terkait studi mahasiswa. Angket adalah daftar pertanyaan yang diberikan kepada orang lain untuk memberikan respons (responden) sesuai dengan permintaan pengguna. yang berisi pernyataanpernyataan disertai dengan jawabannya untuk mengetahui sejauh mana kemampuan Manajerial Pendidikan Islam seorang ketua prodi dan bagaimana penerapan manajemen waktu oleh ketua prodi di lingkungan PTKIS Kota Batam serta bagaimana lulusan mahasiswa di PTKIS Kota Batam, yang disajikan dengan bentuk tertutup. Adapun konstruksi penelitian digambar sebagai berikut:

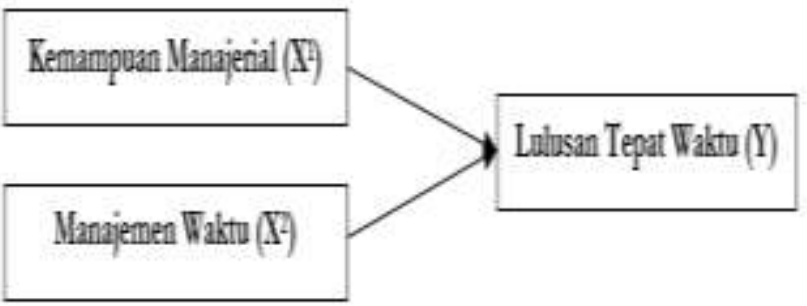

Analisis data penelitian menggunakan persamaan regresi linear berganda, dengan rincian rumusan sebagai berikut :

$\mathrm{Y}=\mathrm{a}+\mathrm{b}_{1} \mathrm{X}_{1}+\mathrm{b}_{2} \mathrm{X}_{2}$

dalam penelitian ini :

$\mathrm{Y}=$ Variabel terikat $:$ lulusan tepat waktu

a = Bilangan konstan

$\mathrm{b}_{1}=$ Koefisien regresi untuk $\mathrm{X}^{1}$

$\mathrm{b}_{2}=$ Koefisien regresi untuk $\mathrm{X}^{2}$

$\mathrm{X}^{4}=$ Variabel bebas $:$ Kemampuan manajerial

$\mathrm{X}^{2}=$ Variabel bebas: Manajemen Waktu

Nilai-nilai a dan b dapat dihitung dengan menggunakan Rumus dibawah ini.

$\mathrm{a}=(\Sigma \mathrm{v})\left(\Sigma \mathrm{x}^{2}\right)-(\Sigma \mathrm{x})(\Sigma \mathrm{xy})$

$$
\text { b } \begin{array}{r}
\mathrm{n}\left(\Sigma \mathrm{x}^{2}\right)-(\Sigma \mathrm{x})^{2} \\
\mathrm{n}(\Sigma \mathrm{xy})-(\Sigma \mathrm{x})(\Sigma \mathrm{y}) \\
\mathrm{n}\left(\Sigma \mathrm{x}^{2}\right)-(\Sigma \mathrm{x})^{2}
\end{array}
$$

variabel kemampuan Manajerial Pendidikan Islam ketua prodi yang dilihat dari empat aspek. Keempat aspek tersebut yaitu ditinjau dari aspek perencanaan, aspek pengorganisasian, aspek penggerakan, dan aspek pengawasan.

1. Aspek perencanaan dalam variabel Manajerial Pendidikan Islam ketua prodi yang dijabarkan ke dalam sub aspek yaitu penyusunan perencanaan, penyusunan rencana operasional pengembangan program studi, dan penyusunan kalender akademik. Aspek perencanaan dalam variabel kemampuan Manajerial Pendidikan Islam ketua prodi yang dijabarkan ke dalam sub aspek yaitu penyusunan perencanaan, penyusunan rencana operasional pengembangan program studi, dan penyusunan kalender akademik.

2. Aspek pengorganisasian dalam variabel kemampuan Manajerial Pendidikan Islam 
ketua prodi yang dijabarkan ke dalam sub aspek yaitu pengembangan organisasi prodi, menciptakan budaya organisasi di lingkungan prodi, dan menciptakan iklim organisasi.

3. Aspek penggerakan dalam variabel kemampuan Manajerial Pendidikan Islam ketua prodi yang dijabarkan ke dalam sub aspek yaitu mengelola dosen dan staf dalam pemberdayaan SDM, mengelola sarana dan prasarana, mengelola humas, mengelola mahasiswa, mengelola pengembangan kurikulum, mengelola keuangan prodi, mengelola ketatausahaan prodi, mengelola unit layanan khusus kampus, mengelola sistem informasi kampus, dan memanfaatkan kemajuan teknologi informasi kampus.

4. Aspek pengawasan dalam variabel kemampuan Manajerial Pendidikan Islam ketua prodi yang dijabarkan ke dalam sub aspek yaitu monitoring pelaksanaan program kegiatan prodi, evaluasi pelaksanaan program kegiatan prodi serta merencanakan tindak lanjut

\section{HASIL dan PEMBAHASAN}

Kemampuan Manajerial Pendidikan Islam dan Manajemen waktu Ketua Prodi dalam menghasilkan lulusan tepat waktu.

a. Kemampuan Manajerial Pendidikan Islam ketua prodi

Seluruh indikator dari konsep operasional dijabarkan ke dalam sub aspek yang ditetapkan sebagai pernyataanpernyataan ke dalam bentuk angket. Keseluruhan angket telah disebarkan dan diisi oleh 6 responden. Berikut adalah hasil dari rekapitulasi deskripsi data kemampuan Manajerial Pendidikan Islam ketua prodi PTKIS Kota Batam.Hasil Penelitian dan Pembahasan Variabel $\mathrm{X}^{1} \quad$ Kemampuan Manajerial Pendidikan Islam Ketua Prodi PTKIS Kota Batam.

Rekapitulasi hasil persentasi tertinggi dari keseluruhan aspek kemampuan Manajerial Pendidikan Islam ketua prodi PTKIS Kota Batam adalah aspek kepemimpinan ketua prodi yang indikatornya meliputi, pelaksanaan tugas yang menjadi tanggung jawab ketua prodi, penanaman kedisiplinan untuk seluruh warga kampus, pelaksanaan pembagian tugas dosen berdasarkan kemampuan dosen, mendorong kegiatan kampus yang kreatif, pengampilan keputusan secara cepat dan tepat, memberikan informasi terbaru dan berbagai ketrampilan kepada dosen dan staf, melakukan komunikasi terbuka kepada dosen dan staf, mendengarkan dan menanggapi keluhan dari dosen dan staf, menyediakan kebutuhan warga kampus, kemampuan menempatkan diri sesuai kondisi, dan kemampuan menggunakan pendekatan yang mendalam apabila terdapat masalah pada warga kampus, yakni (87\%) yang dikategorikan tinggi.

Kemudian hasil persentasi paling lemah dari rekapitulasi per aspek kemampuan Manajerial Pendidikan Islam ketua prodi PTKIS di Kota batam adalah aspek pengawasan yang dilakukan oleh ketua prodi yang indikatornya meliputi, perencanaan, pelaksanaan dan pengawasan 
administrasi program prodi serta pengawasan dan evaluasi pelaksanaan perkuliahan, setelah dievaluasi aspek ini mencapai $(75 \%)$ yang masih dikategorikan sedang.

Total skor keseluruhan dari seluruh aspek dalam variabel kemampuan Manajerial Pendidikan Islam ketua prodi di lingkungan PTKIS Kota Batam adalah 331 yang dikategorikan tinggi karena presentasi tersebut mencapai $81.1 \%$ dari hasil data ideal yaitu 408.

Sehingga dapat disimpulkan bahwa hasil penelitian tentang bagaimana kemampuan Manajerial Pendidikan Islam ketua prodi PTKIS Kota Batam secara keseluruhan hasil penelitiannya tinggi, ini menunjukkan ketua prodi PTKIS Kota Batam mampu merencanakan, mengorganisasikan, menggerakan dan melakukan pengawasan terhadap seluruh komponen prodi dengan baik dan hasil persentasi dikategorikan tinggi. Untuk uraian selanjutnya akan disajikan data penelitian per aspek kemampuan Manajerial Pendidikan Islam ketua prodi PTKIS Kota Batam.

b. Penerapan manajemen waktu oleh ketua prodi

Berikut adalah hasil dari rekapitulasi deskripsi data penerapan Manajemen waktu dari ketua prodi PTKIS Kota Batam. Rekapitulasi hasil persentasi tertinggi dari keseluruhan aspek Manajemen waktu dari ketua prodi PTKIS Kota Batam adalah aspek Pengendalian waktu dengan penjadwalan yang tepat yaitu dengan membuat dan melaksanakan kalender akademik secara disiplin, pelaksanaan perkuliahan, UTS, UAS tepat waktu, dan menjalankan bimbingan skripsi dengan teratur dan terjadwal, serta penggunaan waktu dengan efektif dan efisien. yaitu dengan mempersiapkan sebaik mungkin pelaksaan akreditasi, menata dan mengatur administrasi kelembagaan dengan efektif dan efisien, serta memaksimalkan sumber daya materi agar dapat menghasilkan tepat waktu, dan memiliki produktifitas yaitu memantau dan mengevaluasi kinerja dosen agar dapat menghasilkan perkuliahan yang berkualitas, memberikan contoh dan menerapkan kedisiplinan kepada dosen dan mahasiswa, serta memastikan mutu lulusan yang berkualitas sesuai dengan target yang ditetapkan, yakni (88\%) yang dikategorikan tinggi.

Kemudian hasil persentasi paling rendah dari rekapitulasi per-aspek Manajemen waktu dari ketua prodi PTKIS di Kota batam adalah aspek menertibkan administrasi prodi dan pelaksanaan evaluasi perkuliahan, aspek ini mencapai (75\%) yang masih dikategorikan sedang.

Total skor keseluruhan dari seluruh aspek dalam variabel manajemen waktu dari ketua prodi di lingkungan PTKIS Kota Batam adalah 338 yang dikategorikan tinggi karena presentasi tersebut mencapai 83\% dari hasil data ideal yaitu 408 .

Sehingga dapat disimpulkan bahwa hasil penelitian tentang bagaimana manajemen waktu dari ketua prodi PTKIS Kota Batam secara keseluruhan hasil penelitiannya tinggi, ini menunjukkan ketua 
prodi PTKIS Kota Batam mampu menjadwalkan, melakasanakan kalender akademik dan menertibkan pelaksanaan perkuliahan secara efektif dan efisien agar dapat memaksimalkan terhadap seluruh komponen prodi dengan baik dan hasil persentasi dikategorikan tinggi. Untuk uraian selanjutnya akan disajikan data penelitian per aspek kemampuan Manajerial Pendidikan Islam ketua prodi PTKIS Kota Batam.

c. Perkembangan mahasiswa lulusan tepat waktu

Keseluruhan angket telah disebarkan dan diisi oleh 6 responden. Berikut adalah hasil dari rekapitulasi deskripsi data lulusan tepat waku di PTKIS Kota Batam. Rekapitulasi hasil persentasi tertinggi dari keseluruhan aspek lulusan tepat waktu di PTKIS Kota Batam adalah aspek menyelesaikan studi S1 kurang atau selama 4 tahun yaitu dengan mengikuti perkuliahan sesuai dengan kalender akademik, dapat menyelesaikan bimbingan skripsi, dan mengikuti UTS, UAS, munaqosah, yudisium hingga wisuda tepat waktu yakni (88\%) yang dikategorikan tinggi.

Kemudian hasil persentasi paling lemah dari rekapitulasi per aspek lulusan tepat waktu di PTKIS Kota batam adalah aspek merencanakan penelitian dari awal masa perkuliahan, menyusun jadwal perkuliahan sesuai dengan SKS dan menyelesaikan administrasi kuliah maka aspek ini mencapai (75\%) yang masih dikategorikan sedang.

Total skor keseluruhan dari aspek menyelesaikan Studi S1 kurang atau selama 4 tahun dalam variabel lulusan tepat waktu di PTKIS Kota Batam adalah 331 yang dikategorikan tinggi karena rata-rata persentasi dari aspek variabel lulusan tepat waktu tersebut mencapai $81 \%$ dari hasil data ideal yakni 408 .

1. Pengaruh kemampuan Manajerial Pendidikan Islam dan Manajemen waktu ketua prodi terhadap lulusan tepat waktu

a. Pengaruh kemampuan Manajerial Pendidikan Islam ketua prodi terhadap lulusan tepat waktu

Data yang ada akan diuji dengan uji $\mathrm{T}$ parsial apakah variabel $\mathrm{X}^{1}$ Kemampuam Manajerial Pendidikan Islam mempunyai pengaruh secara parsial terhadap variabel Y. adapun hipótesis yang diajukan dalam penelitian ini adalah : H1 adalah adanya pengaruh $\mathrm{X}^{1}$ kemampuan Manajerial Pendidikan Islam terhadap Variabel Y lulusan tepat waktu.

Untuk melakukan uji hipótesis di atas maka akan dilakukan uji t Parsial untuk mendapatkan acuan dalam menyimpulkan dengan dua cara, pertama melihat nilai signifikan (sig) dan kedua membandingkan antara nilai $\mathrm{T}_{\text {hitung }}$ dengan $\mathrm{T}_{\text {tabel. }}$

b. Berdasarkan nilai signifikasi (sig) :

1) Jika nilai signifikansi (sig) < dari nilai probablitas 0.05 maka ada pengaruh variabel bebas $\mathrm{X}^{1}$ terhadap Variabel terikat $\mathrm{Y}$ atau hipótesis diterima.

2) Jika nilai signifikansi (sig) $>$ dari nilai probablitas 0.05 maka tidak ada pengaruh variabel bebas $\mathrm{X}^{1}$ terhadap Variabel terikat $\mathrm{Y}$ atau hipótesis ditolak. Maka karena nilai 
signifikansi (sig) berdasarkan tabel 19 diatas adalah $\mathrm{X}^{1}$ nilai sig $0.016<0.05$ maka H1 diterima.

c. Berdasarkan perbandingan nilai $t_{\text {hitung }}$ dengan $\mathrm{t}_{\text {tabel }}$ :

Berdasarkan output SPSS di atas diketahui nilai $T_{\text {hitung }}$ variabel Kemampuan Manajerial Pendidikan Islam $\mathrm{X}^{1}$ adalah 4.963, karena $\mathrm{T}_{\text {Hitung }} 4.963>$ dari $\mathrm{T}_{\text {Tabel }} 3.182$ maka $\mathrm{H1}$ diterima, maka berarti Varibel $\mathrm{X}^{1}$ kemampuan Manajerial Pendidikan Islam mempunyai pengaruh secara parsial terhadap variabel $\mathrm{Y}$ lulusan tepat waktu.

Sehingga dapat disimpulkan bahwa hasil penelitian tentang bagaimana kemampuan Manajerial Pendidikan Islam ketua prodi PTKIS Kota Batam secara keseluruhan hasil penelitiannya tinggi, ini menunjukkan ketua prodi PTKIS Kota Batam mampu merencanakan, mengorganisasikan, menggerakan dan melakukan pengawasan terhadap seluruh komponen prodi dengan baik dan hasil persentasi dikategorikan tinggi. Untuk uraian selanjutnya akan disajikan data penelitian per aspek kemampuan Manajerial Pendidikan Islam ketua prodi PTKIS Kota Batam.

d. Pengaruh manajemen waktu terhadap lulusan tepat waktu

Dari data diatas akan diuji dengan uji $\mathrm{T}$ parsial, apakah variabel $\mathrm{X}^{2}$ masing masing mempunyai pengaruh secara parsial terhadap variabel Y. Adapun hipótesis yang diajukan dalam penelitian ini adalah : $\mathrm{H} 2$ adalah adanya pengaruh $\mathrm{X}^{2}$ manajemen waktu terhadap variabel Y lulusan tepat waktu. Untuk melakukan uji hipótesis di atas maka akan dilakukan uji t Parsial untuk mendapatkan acuan dalam menyimpulkan dengan dua cara, pertama melihat nilai signifikan (sig) dan kedua membandingkan antara nilai $\mathrm{T}$ hitung dengan $\mathrm{T}$ tabel.

1) Berdasarkan nilai signifikasi (sig):

a) Jika nilai signifikansi (sig) $<$ dari nilai probablitas 0.05 maka ada pengaruh variabel bebas $\mathrm{X}^{2}$ terhadap Variabel terikat $\mathrm{Y}$ atau hipótesis diterima.

b) Jika nilai signifikansi (sig) $>$ dari nilai probablitas 0.05 maka tidak ada pengaruh variabel bebas $\mathrm{X}^{2}$ terhadap Variabel terikat $\mathrm{Y}$ atau hipótesis ditolak. Maka karena nilai signifikansi (sig) berdasarkan tabel 19 diatas adalah nilai signifikansi dari $\mathrm{X}^{2}$ adalah 0.077 $>0.05$ maka H2 ditolak.

2) Berdasarkan perbandingan nilai $t$ hitung dengan $\mathrm{t}$ tabel :

Berdasarkan output SPSS di atas diketahui nilai $\mathrm{T}$ hitung variabel $\mathrm{X}^{2}$ Manajemen waktu adalah $2.654<$ dari $\mathrm{T}$ tabel 3,812 maka H2 ditolak, yang berarti variabel $\mathrm{X}^{2}$ manajemen waktu tidak memiliki pengaruh secara parsial terhadap variabel Y lulusan tepat waktu.

\section{Pengaruh kemampuan Manajerial} Pendidikan Islam dan manajemen waktu secara bersama-sama terhadap lulusan tepat waktu

hasil rekapitulasi keseluruhan dari 3 variabel, yaitu variabel $\mathrm{X}^{1}$ Kemampuan Manajerial Pendidikan Islam ketua prodi, variabel $\mathrm{X}^{2}$ Manajemen waktu ketua prodi dan variabel Y lulusan tepat waktu adalah 1020 dengan prosentasi $83,3 \%$ yang berarti masuk kategori sangat tinggi, Sedangkan berdasarkan data tabel 21,22,23 diperoleh data sebagai berikut : 
1. Tingkat kemampuan Manajerial Pendidikan Islam Ketua Prodi PTKIS Kota Batam sebesar $81,1 \%$ yang masuk kategori tinggi.

2. Tingkat Penerapan Manajemen waktu Ketua Prodi PTKIS Kota Batam adalah sebesar $83 \%$ dan masuk kategori tinggi.

3. Tingkat Hasil Lulusan Mahasiswa PTKIS Kota Batam adalah $81 \%$ dan juga masuk kategori tinggi.

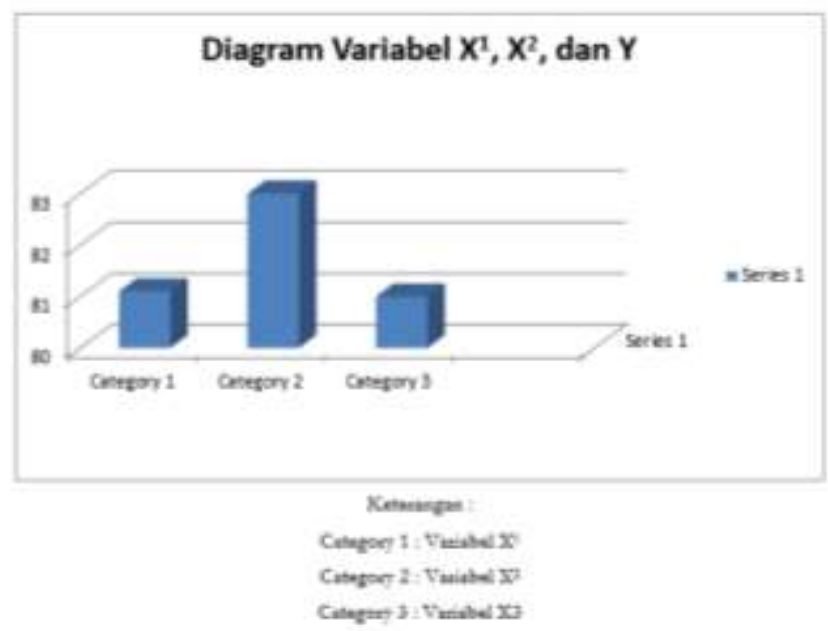

Dari keseluruhan data hasil penelitian ini menunjukkan tentang sama-sama tingginya ketiga aspek variabel penelitian ini, sehingga diindikasi ketiga variabel ini memiliki keterkaitan dan hubungan/pengaruh.

Untuk menunjukkan ada dan tidaknya pengaruh dari variabel $\mathrm{X}^{1}$ dan $\mathrm{X}^{2}$ terhadap Variabel Y, maka kemudian akan dilakukan analisis untuk mengetahui pengaruh variabel Kemampuan Manajerial Pendidikan Islam dan Manajemen waktu terhadap lulusan tepat waktu PTKIS di Kota Batam.

Analisis yang dilakukan meliputi: persamaan regresi linier berganda, determinasi, korelasi dan uji signifikansi dengan $t_{\text {test }}$ pada tingkat $\alpha=5 \%$.

Analisis persamaan regresi linier berganda ini digunakan untuk mengetahui pola pengaruh variabel bebas Kemampuan Manajerial Pendidikan Islam $\left(\mathrm{X}^{1}\right)$, Manajemen Waktu $\left(\mathrm{X}^{2}\right)$, terhadap variabel terikat lulusan tepat waktu $(\mathrm{Y})$, dengan persamaan umum : $\mathrm{Y}=$ $\mathrm{a}+\mathrm{b}_{1} \mathrm{X}_{1}+\mathrm{b}_{2} \mathrm{X}_{2}$ dalam penelitian ini :

$\mathrm{Y}=$ Variabel terikat : lulusan tepat waktu

$\mathrm{a}=$ Bilangan konstan

$\mathrm{b}_{1}=$ Koefisien regresi untuk $\mathrm{X}^{1}$

$\mathrm{b}_{2}=$ Koefisien regresi untuk $\mathrm{X}^{2}$

$\mathrm{X}^{1}=$ Variabel bebas : Kemampuan Manajerial

Pendidikan Islam

$\mathrm{X}^{2}=$ Variabel bebas: Manajemen Waktu

Dari hasil perhitungan pada data, dapat disajikan Tabel berikut yang memuat koefisien regresi sebagai berikut.

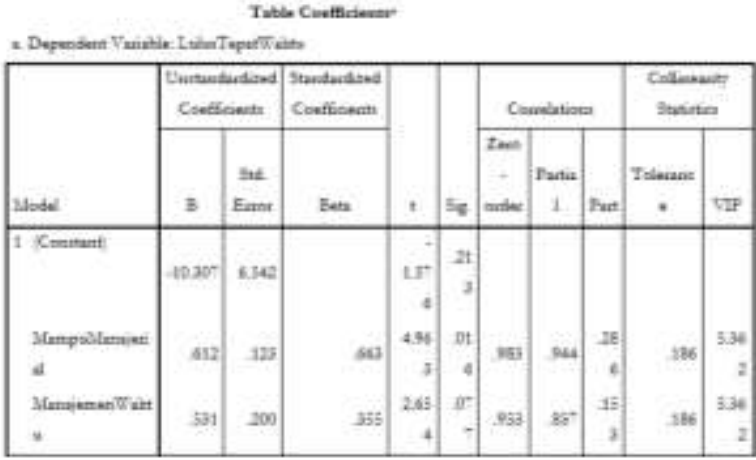

Dari Tabel 25 diatas, dapat diketahui nilai konstanta a, koefisien regresi variabel Kemampuan Manajerial Pendidikan Islam ( $\left.b_{1}\right)$, manajemen waktu $\left(\mathrm{b}_{2}\right)$ yaitu :

$$
\begin{aligned}
& \mathrm{a}=-10.307 \\
& \mathrm{~b}_{1}=0,612 \\
& \mathrm{~b}_{2}=0,531
\end{aligned}
$$

Berdasarkan data di atas, dapat dibuat persamaan regresi linier berganda pola pengaruh variabel bebas Kemampuan Manajerial Pendidikan Islam $\left(\mathrm{X}^{1}\right)$, Manajemen Waktu $\left(\mathrm{X}^{2}\right)$ terhadap variabel terikat lulusan tepat waktu $(\mathrm{Y})$, sebagai berikut :

$$
\begin{aligned}
& Y=a+b_{1} X^{1}+b_{2} X^{2} \\
& Y=-10,307+0,612 X^{1}+0,531 X^{2}
\end{aligned}
$$


Dari hasil persamaan yang diperoleh ini, dapat dijelaskan pola pengaruh variabel bebas Kemampuan Manajerial Pendidikan Islam $\left(\mathrm{X}^{1}\right)$, Manajemen Waktu $\left(\mathrm{X}^{2}\right)$ terhadap variabel terikat lulusan tepat waktu (Y), di atas, adalah sebagai berikut :

a. Variabel $\mathrm{X}^{1}$ menjadi variabel paling dominan berpengaruh terhadap vaiabel $\mathrm{Y}$ dengan nilai koefisien sebesar 0,612 sedangkan variabel $\mathrm{X}^{2}$ hanya memiliki nilai koefisien lebih sedikit 0,531 .

b. Terdapat pola pengaruh positif variabel bebas Kemampuan Manajerial Pendidikan Islam $\left(\mathrm{X}^{1}\right)$ terhadap variabel terikat Lulusan Tepat waktu (Y), terdapat pola pengaruh positif variabel bebas Manajemen Waktu $\left(\mathrm{X}^{2}\right)$ terhadap variabel terikat lulusan tepat waktu $(Y)$.

c. Apabila skor variabel bebas Kemampuan Manajerial Pendidikan Islam $\left(\mathrm{X}^{1}\right)$, Manajemen waktu $\left(\mathrm{X}^{2}\right)$ masing-masing besarnya sama dengan 0 , maka skor lulusan tepat wakyu (Y) adalah sebesar konstanta (a), yaitu $-10,307$ satuan. Hal ini didapat dari perhitungan:

$$
\begin{aligned}
& Y=a+b_{1} X_{1}+b_{2} X_{2} \\
& Y=-10,307+0,612 X_{1}+0,531 X_{2} \\
& Y=-10,307+0,612 \times 0+0,531 \times 0 \\
& Y=-10,307+0+0+0+0+0 \\
& Y=-10,307
\end{aligned}
$$

Ini berarti baru mulai terdapat lulusan tepat waktu (Y) apabila skor Kemampuan Manajerial Pendidikan Islam $\left(\mathrm{X}^{1}\right)$, manajemen waktu $\left(\mathrm{X}^{2}\right)$ telah mencapai skor (nilai) tertentu di atas nol.

a. Apabila skor variabel bebas Kemampuan Manajerial Pendidikan Islam $\left(\mathrm{X}^{1}\right)$, manajemen waktu $\left(\mathrm{X}^{2}\right)$ masing-masing meningkat satu satuan. Atau, Kemampuan
Manajerial Pendidikan Islam $\left(\mathrm{X}^{1}\right)$, manajemen waktu $\left(\mathrm{X}^{2}\right)$ masing-masing menjadi satu satuan, maka persamaan regresi linier berganda tersebut akan menjadi :

$\mathrm{Y}=\mathrm{a}+\mathrm{b}_{1} \mathrm{X}_{1}+\mathrm{b}_{2} \mathrm{X}_{2}$

$\mathrm{Y}=-10,307+0,612 \mathrm{X}_{1}+0,531 \mathrm{X}_{2}$

$\mathrm{Y}=-10,307+0,612 \times 1+0,531 \times 1$

$\mathrm{Y}=-10,307+0,612+0,531$

$$
=-9,164
$$

Ini berarti apabila Kemampuan Manajerial Pendidikan Islam $\left(\mathrm{X}^{1}\right)$, manajemen waktu $\left(\mathrm{X}^{2}\right)$ masing-masing satu satuan, maka besarnya lulusan tepat waktu (Y) dari -10,307 satuan menjadi sebesar -9,164satuan atau lulusan tepat waktu (Y) meningkat sebesar = 9,164- $(-10,307)=1,143$ satuan.

Bedasarkan penjelasan di atas, secara umum dapat dinyatakan bahwa Kemampuan Manajerial Pendidikan Islam $\left(\mathrm{X}^{1}\right)$, Manajemen Waktu $\left(\mathrm{X}^{2}\right)$ secara bersama memiliki pola pengaruh positif terhadap lulusan tepat waktu (Y).

Ini menunjukkan bahwa apabila Kemampuan Manajerial Pendidikan Islam $\left(\mathrm{X}^{1}\right)$, Manajemen waktu $\left(\mathrm{X}^{2}\right)$, secara besama-sama ditingkatkan, maka lulusan tepat waktu (Y) akan meningkat. Sebaliknya, apabila Kemampuan Manajerial Pendidikan Islam $\left(\mathrm{X}^{1}\right)$, manajemen waktu $\left(\mathrm{X}^{2}\right)$ secara besama-sama menurun, maka akan terjadi penurunan lulusan tepat waktu (Y).

Analisis ini digunakan untuk mengetahui persentasi besarnya pengaruh variabel yang diteliti, yaitu antara variabel bebas Kemampuan Manajerial Pendidikan Islam $\left(\mathrm{X}^{1}\right)$, Manajemen waktu $\left(\mathrm{X}^{2}\right)$ secara bersama-sama terhadap variabel terikat lulusan tepat waktu (Y). 
Dari hasil perhitungan pada Lampiran 5, dapat disajikan Tabel berikut yang memuat koefisien korelasi kwadrat (R square) sebagai berikut :

Table Model Summan

\begin{tabular}{|c|c|c|c|c|c|}
\hline $\begin{array}{l}\text { Mod } \\
\text { el }\end{array}$ & R & R. Squere & $\begin{array}{l}\text { Adpostad R } \\
\text { Squere }\end{array}$ & $\begin{array}{l}\text { Std. Exror of } \\
\text { the Estimate }\end{array}$ & $\begin{array}{l}\text { Dorbin: } \\
\text { Watson }\end{array}$ \\
\hline 1 & $995^{\circ}$ & 990 & 983 & 1.564 & 1760 \\
\hline
\end{tabular}

Rumus untuk menentukan besarnya koefisien determinasi $\mathrm{D}=\mathrm{R}^{2} \mathrm{x} 100 \%$. Besarnya $\mathrm{R}^{2}$ (R-square) sesuai Tabel 6 diatas $=$ 0,990. Karena besarnya $\mathrm{R}^{2}=0,990$, maka :

$$
\begin{aligned}
\mathrm{D} & =\mathrm{R}^{2} \times 100 \% \\
& =0,990 \times 100 \% \\
& =99 \%
\end{aligned}
$$

Koefisien determinasi (D) sebesar $99 \%$, berarti lulusan tepat waktu (Y) dipengaruhi Kemampuan Manajerial Pendidikan Islam $\left(\mathrm{X}^{1}\right)$, manajemen waktu $\left(\mathrm{X}^{2}\right)$ secara bersama-sama sebesar $99 \%$. Sisanya sebesar $100 \%-99 \%=$ 0,01\% dipengaruhi oleh faktor lain yang tidak diteliti pada kesempatan ini. Pengaruh Kemampuan Manajerial Pendidikan Islam $\left(\mathrm{X}^{1}\right)$, manajemen waktu $\left(\mathrm{X}^{2}\right)=99 \%$, menunjukkan besarnya sumbangan kombinasi Kemampuan Manajerial Pendidikan Islam $\left(\mathrm{X}^{1}\right)$, manajemen waktu $\left(\mathrm{X}^{2}\right)$ dalam meningkatkan lulusan tepat waktu (Y).

Analisis ini digunakan untuk mengetahui tinggi-rendahnya hubungan antar variabel yang diteliti, yaitu antara variabel Kemampuan manajeril $\left(\mathrm{X}^{1}\right)$, Manajemen waktu $\left(\mathrm{X}^{2}\right)$ secara bersama-sama terhadap variabel Lulusan tepat waktu (Y).

Dari data di atas dapat diketahui koefisien korelasi $(\mathrm{R})=0,995$. Koefisien korelasi ( $\mathrm{R}$ ) sebesar 0,995, berarti variable kemampuan Manajerial Pendidikan Islam $\left(\mathrm{X}^{1}\right)$,
Manajemen waktu $\left(\mathrm{X}^{2}\right)$ secara bersama-sama memiliki hubungan positip yang tinggi terhadap variable lulusan tepat waktu $(\mathrm{Y})$.

Untuk menguji signifikan-tidaknya pengaruh variabel bebas Kemampuan Manajerial Pendidikan Islam $\left(\mathrm{X}^{1}\right)$, manajemen waktu $\left(\mathrm{X}^{2}\right)$ secara bersama-sama terhadap variabel terikat lulusan tepat waktu (Y), maka dilakukan pengujian dengan menggunakan uji-F $\left(\mathrm{F}_{\text {-test }}\right)$ yang langkah-langkah pengujiannya adalah sebagai berikut : Hipotesis yang diajukan dalam pengujian ini adalah "Ada pengaruh positif dan signifikan kemampuan Manajerial Pendidikan Islam $\left(\mathrm{X}^{1}\right)$, manajemen waktu $\left(\mathrm{X}^{2}\right)$, terhadap lulusan tepat waktu". Sesuai dengan hipotesis tersebut, maka hipotesis kerja dapat dirumuskan sebagai berikut :

a. $\mathrm{H}_{0}: \mathrm{b}_{1}=\mathrm{b}_{2}=0$, berarti bahwa "Tidak ada pengaruh positif dan signifikan kemampuan Manajerial Pendidikan Islam, manajemen waktu terhadap lulusan tepat waktu".

b. $\mathrm{H}_{\mathrm{a}}: \mathrm{b}_{1}>0$ dan atau $\mathrm{b} 2>0$ berarti bahwa"Ada pengaruh positif dan signifikan dari kemampuan Manajerial Pendidikan Islam dan manajemen waktu terhadap lulusan tepat waktu".

Dalam pengujian ini digunakan $\mathrm{F}_{\text {tabel }}=$

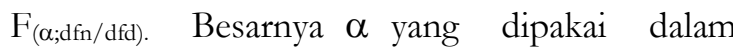
pengujian ini adalah sebesar 5\% dengan dfn (degrees of freedom numerator $=$ derajat bebas pembilang) $=\mathrm{k}=2$, dan $\mathrm{dfd}$ (degres of freedom denominator $=$ derajat bebas penyebut $)=(\mathrm{k} ; \mathrm{n}$ $-\mathrm{k})=(2 ; 6-2)=(2 ; 4)$. Sesuai dengan Tabel F menurut Husaini Usman (1995:313316) pada Lampiran 6, besarnya $\mathrm{F}(\alpha ; \mathrm{dfn} / \mathrm{dfd})$ untuk $\mathrm{F}_{(5 \% ; 5 / 69)}$ adalah $=6.94$

Kriteria Penerimaan / Penolakan Hipotesis 
Adapun kriteria penerimaan atau penolakan hipotesis dalam uji $\mathrm{F}$ menggunakan dua cara,yaitu :

a. membandingkan nilai signifikansi(sig) dengan nilai probabilitas hasil output anova. Jika nilai sig. < 0.005, maka hipótesis diterima, sehingga variabel $\mathrm{X}^{1}$ dan $\mathrm{X}^{2}$ mempunyai pengaruh secara simultan/ bersama sama terhadap variabel Y. namun jika nilai sig. > 0.005, maka hipótesis ditolak, berarti bahwa variabel $\mathrm{X}^{1}$ dan $\mathrm{X}^{2}$ tidak memiliki pengaruh yang simultan terhadap variabel $\mathrm{Y}$.

b. berdasarkan perbandingan nilai $\mathrm{F}$ hitung dengan $\mathrm{F}$ tabel

1) Apabila $F_{\text {hitung }}>F_{\text {tabel }}$ maka $\mathrm{H}_{\mathrm{a}}$ diterima. Maka variabel $\mathrm{X}^{1}$ kemampuan Manajerial Pendidikan Islam bersama variabel $\mathrm{X}^{2}$ manajemen waktu memiliki pengaruh simultan terhadap Variabel Y lulusan tepat waktu.

2) Apabila $F_{\text {hitung }}<F_{\text {tabel }}$ maka $\mathrm{H}_{\mathrm{a}}$ ditolak. Maka berarti variabel $\mathrm{X}^{1}$ kemampuan Manajerial Pendidikan Islam dan variabel $\mathrm{X}^{2}$ manajemen waktu tidak memiliki pengaruh secara simultan terhadap variabel Y lulusan tepat waktu.

Penentuan F hitung

Dari hasil perhitungan SPSS for Windows versi 19.0 pada Lampiran 1, dapat dibuat Tabel berikut.

Table ANOVA $=$

\begin{tabular}{|l|r|r|r|r|r|}
\hline Model & \multicolumn{1}{|c|}{$\begin{array}{l}\text { Sum of } \\
\text { Squares }\end{array}$} & df & $\begin{array}{c}\text { Mean } \\
\text { Square }\end{array}$ & F & Sig- \\
\hline Regression & 727.492 & 2 & 363.746 & 148.6 & .001 \\
Residual & 7.341 & 3 & 2.447 & & \\
Total & 734.833 & 5 & & & \\
\hline
\end{tabular}

a. Dependent Variable: Lulus'T'epatWaktu

b. b. Predictors: (Constant), ManajemenW/aktu, MampuManajerial
Dari data diatas, terlihat pada $\mathrm{dfn}=$ derajat bebas pembilang $=2$ dan $\mathrm{dfd}=$ derajat bebas penyebut $=3$, diperoleh besarnya $\mathrm{F}_{\text {hitung }}=$ 148,643 dan Nilai Sig.hitung $=0,001$.

Penarikan Kesimpulan Uji

a. berdasarkan data pada Tabel output SPSS di atas, diketahui nilai sig. adalah 0,001. Karena nilai sig. 0,001 < 0.05 maka sesuai dengan dasar pengambilan keputusan dalam uji $\mathrm{F}$ dapat disimpulkan bahwa hipotesis diterima atau dengan kata lain variabel $\mathrm{X}^{1}$ Kemampuan Manajerial Pendidikan Islam dan variabel $\mathrm{X}^{2}$ manajemen waktu secara simultan berpengaruh terhadap variabel $\mathrm{Y}$ lulusan tepat waktu.

b. berdasarkan data pada Tabel output SPSS di atas, diketahui nilai $\mathrm{F}$ hitung adalah 148.643. Karena nilai $\mathrm{F}$ hitung $148.643>6.94$ maka sesuai dengan dasar pengambilan keputusan dalam uji $F$ dapat disimpulkan bahwa hipotesis diterima atau dengan kata lain variabel $\mathrm{X}^{1}$ Kemampuan Manajerial Pendidikan Islam dan variabel $\mathrm{X}^{2}$ manajemen waktu secara simultan berpengaruh terhadap variabel $\mathrm{Y}$ lulusan tepat waktu.

Dengan demikian hipotesis yang menyatakan : "semakin bagus kemampuan Manajerial Pendidikan Islam ketua prodi dan penerapan manajemen waktu maka akan semakin tinggi jumlah mahasiswa yang lulus tepat waktu pada perguruan tinggi agama islam di lingkungan PTKIS Kota Batam" teruji kebenarannya.

Untuk melengkapi hasil angket yang diperoleh mengenai kemampuan Manajerial Pendidikan Islam dan penerapan manajemen 
waktu oleh ketua prodi, berikut akan di uraikan dari hasil wawancara dengan 6 ketua prodi di lingkungan PTKIS Kota Batam.

Antara lain dalam hal perencanaan, ketua prodi menyatakan merasa telah menempatkan atau menugaskan dosen dan staff sesuai dengan kemampuannya sebagai dosen/ staff. dan dalam mengelola prodi, ketua prodi selalu membuat perincian tugas dan target yang jelas yang tertuang dalam kalender akademik untuk diketahui oleh semua dosen dan staff serta mahasiswa sehingga terdapat keterbukaan dalam hal menjalankan kalender akademik.

Dalam hal organizingketua prodi menyampaikan dengan baik kepada staff dan dosen untuk selalu mengacu pada kalender akademik yang sudah ditetapkan, serta mengarahkan para dosen agar selalu menyelesaikan agenda yang telah dirapatkan bersama.

sedangkan dalam hal penggerakkan para ketua prodi menyatakan selalu mengarahkan dan menggerakkan dosen dan staf agar dapat bekerja sesuai dengan kalender akademik dalam menghasilkan lulusan mahasiswa tepat waktu. dan dalam hal evaluasi ketua prodi menyatakan bahwa selalu mengadakan rapat setiap akhir bulan untuk mendiskusikan tentang hal yang berkaitan dengan peningkatan mutu lulusan dan mengunakan hasil evaluasi untuk perbaikan kedepanya. Sebagaimana yang terlampir pada lampiran...

Dari uraian di atas dapat disimpulkan kemampuan Manajerial Pendidikan Islam ketua prodi di lingkungan PTKIS Kota Batam dalam kategori "baik" dengan rata-rata keseluruhan yang mencakup perencanaan, pengorganisasian, penggerakan dan evaluasi mencapai 83,3\%.

\section{KESIMPULAN}

Berdasarkan hasil analisis data dan perhitungan statistik seperti yang telah diuraikan, maka dapat diambil beberapa kesimpulan sebagai berikut:

1. Kemampuan Manajerial Pendidikan Islam ketua prodi di lingkungan PTKIS Kota Batam menunjukkan pada tingkatan yang tinggi, hal ini dapat dilihat dari total skor keseluruhan seluruh aspek dalam variabel kemampuan Manajerial Pendidikan Islam ketua prodi di lingkungan PTKIS Kota Batam adalah 331 yang dikategorikantinggi karena presentasi tersebut mencapai 81.1\% dari hasil data ideal yaitu 408.

2. Manajemen waktu yang diterapkan oleh ketua prodi dalam menjalankan perkuliahaan pada lembaga pendidikannya terbukti memperoleh nilai tinggi dalam penelitian ini. Hal ini dibuktikan dengan tingginya total skor keseluruhan dari seluruh aspek dalam variabel manajemen waktu dari ketua prodi di lingkungan PTKIS Kota Batam adalah 338 yang dikategorikan sangat tinggi karena presentasi tersebut mencapai $83 \%$ dari hasil data ideal yaitu 408 .

3. Perkembangan mahasiswa yang dapat lulus tepat waktu di PTKIS Kota Batam juga menunjukkan hasil yang tinggi. Tingginya lulusan mahasiswa di lingkungan PTKIS Kota Batam dapat dilihat dari total skor keseluruhan dari aspek menyelesaikan Studi S1 kurang atau selama 4 tahun dalam variabel lulusan tepat waktu di PTKIS Kota Batam adalah 331. 
4. Pengaruh kemampuan Manajerial Pendidikan Islam ketua prodi terhadap lulusan tepat waktu

5. Pengaruh Manajemen waktu terhadap lulusan tepat waktu secara parcial ternyata tidak terbukti, setelah dilakukan uji t Parsial untuk mendapatkan kesimpulanhasil penelitian yaitu dengan dua cara, pertama melihat nilai signifikan (sig) dan kedua membandingkan antara nilai Thitung dengan $\mathrm{T}^{\text {tabel. }}$.

6. Pengaruh kemampuan Manajerial Pendidikan Islam dan manajemen waktu secara bersamasama terhadap lulusan tepat waktu.

\section{DAFTAR PUSTAKA}

Danim, Sudarwan. (2004). Motivasi, Kepemimpinan, dan Efektivitas Kelompok. Jakarta: Rineka Cipta.

Gitosudarmo, Indriyo. (1990). Prinsip Dasar Manajemen Edisi 2. Yogyakarta: BPFE.

Hadi, Sutrisno. (1991). Analisis Butir Untuk Instrument Angket, Tes dan Skala Nilai. Yogyakarta: FP UGM

Handayaningrat, Soewarno. (2007). Pengantar Studi Ilmu Administrasi dan Manajemen. Jakarta: Bina ksara.

Hartono (2015). Analisis Item Instrumen. Pekanbaru: Zanafa Publishing.

Hasibuan, Malayu S.P. (1996). Organisasi dan Motivasi. Jakarta: Bumi Aksara.

Sedarmayanti. (2002). SDM dan Produktivitas Kerja. Bandung: Mandar Maju.

Sugiyono. (2001). Metode Penelitian Bisnis. Bandung: Penerbit CV. Alfabeta.

Sujana, Nana. (2010). Media pengajaran, Bandung: Sinar baru algensindo offset.

Sukmadinata, Syaodih, Nana. (2012). Metode Penelitian Pendidikan.

Bandung:Rosdakarya.

Sulistyorini. (2009). Manejemen Pendidikan Islam. Yogyakarta: TERAS.

Terry, George R. (2009). Prinsip-prinsip Manajemen. Jakarta: PT Bumi Angkasa. 